\title{
The Long Road to State-Building in Latin America and its Impact on Regionalization Processes*
}

\author{
El largo camino de construcción del Estado en \\ América Latina y su impacto en los procesos de \\ regionalización
}

\author{
Eduardo Pastrana Buelvas ${ }^{* *}$ \\ Rafael Castro Alegría ${ }^{* * *}$
}

Recibido: 05/08/2014

Aprobado: 14/07/2015

Disponible en línea: 30/11/2015

\begin{abstract}
This article addresses, from an interdisciplinary

Resumen

perspective, the impact of the long and tortuous

El artículo aborda, desde una perspectiva state-building process in Latin America on the interdisciplinaria, el impacto que el largo y tortuoso proceso de construcción del Estado development of regionalization processes in en Latinoamérica ha tenido sobre la forma en the subcontinent. Firstly, it contrasts classical que se han desarrollado los procesos de reand contemporary ideas of sovereignty in order gionalización en el subcontinente. Primero, se to establish, in a differentiated shape and from contrastan las ideas clásicas y contemporáneas a historical perspective, the manner in which the sovereignty principle has taken shape in state-building and regionalization processes in both Latin America and Europe. Secondly, sobre la soberanía, a fin de establecer de forma diferenciada la manera en que dicho principio, desde una perspectiva histórica, ha tomado forma en la construcción del Estado y en la conthe thinking surrounding integration and sovereignty in the European continent is briefly summarized. Thirdly, the state-building process of Latin American nation-states and the impact creción de procesos de regionalización tanto en Latinoamérica como en Europa. Segundo, se presentan los elementos generales del pensamiento sobre la integración europea conectándolos con

doi:10.11144/Javeriana.papo20-2.IrsI

\footnotetext{
* Artículo de reflexión

** Profesor titular de la Pontificia Universidad Javeriana y Director del Departamento de Relaciones Internacionales de la Facultad de Ciencia Política y Relaciones Internacionales. Doctor en Derecho Internacional de la Universidad de Leipzig. Correo electrónico: epastrana@javeriana.edu.co

${ }^{* * *}$ Profesor de la Universidad Santiago de Cali e Investigador del Grupo de Investigación en Ciencias Políticas, Derecho y Relaciones Internacionales (GICPODERI). Abogado de la Universidad Santiago de Cali. Correo electrónico: castro.rafael@javeriana.edu.co
} 
it has had on their reluctance to transfer sovereignty to regional governance structures is interpreted. Fourthly, it outlines the role of ideas such as Pan-Americanism, Latin-Americanism, South-Americanism, and Bolivarianism in the development of regionalization processes in Latin America. Fifthly, the characteristics of the three waves of integration and the reluctance of Latin American states to transfer sovereignty to regional governance architectures are defined. Sixth, it establishes the differences in historic circumstances which have influenced different perspectives on the transfer of sovereignty in the construction of the Latin American and European regions. Finally, from the understanding of the problem of unfinished state-building in Latin America, this article evaluates the development of current regionalization processes.

\section{Keywords}

Latin America; State-building; sovereignty; regionalization; ideas

\section{Cómo citar este artículo:}

Pastrana-Buelvas, E. \& Castro Alegría, R. (2015). The long road to State-building in Latin America and its impact on regionalization processes. Papel Político, 2O(2), 523-546. http:// dx.doi.org/10.11144/Javeriana.papo20-2.lrsl su experiencia histórica. Tercero, se interpreta el proceso de construcción de los Estados nación latinoamericanos y el impacto que han tenido en su renuencia a ceder soberanía a entes supranacionales. Cuarto, se destaca el rol que han desempeñado ideas, tales como el panamericanismo, latinoamericanismo, suramericanismo y bolivarismo en el desarrollo de los procesos de regionalización en Latinoamérica. Quinto, se definen los rasgos característicos de las tres olas de integración y la renuencia de los Estados latinoamericanos a transferir soberanía a las arquitecturas de gobernanza regional. Sexto, se compara el concepto de soberanía en América Latina y en Europa así como el impacto que ha tenido en sus respectivos procesos de regionalización. Finalmente a partir de la compresión de la problemática del proceso inconcluso de construcción del Estado en Latinoamérica, se evalúan las perspectivas de desarrollo de los procesos de regionalización actuales.

\section{Palabras clave}

Latinoamérica; formación del Estado; soberanía; regionalización; ideas 


\section{Introduction}

The reluctance of Latin American states to transfer sovereignty to supranational organizations has been a recurrent point of criticism to the integration processes that have taken place in Latin America. Generally, this point arises when comparing them to the European experience. Nevertheless, two important factors are often neglected in the explanations regarding the recurrence of this reluctance. Firstly, the historical difficulties in the state-building process in Latin America, which have contributed to build a different notion of sovereignty. Secondly, the divergent ideas about delimitation of the territory that have been historically fostered, such as Latin Americanism, PanAmericanism and, more recently, South Americanism; ideas that show divisions when it comes to define who is included in the region, because each one entails very different geopolitical and economic interests.

To interpret the impact of these factors in the integration processes, the present article will: a) contrast the classical and contemporary ideas of sovereignty to show conceptual elements, which will allow us to understand the development of this principle in Latin America and in Europe; b) briefly summarize the thinking surrounding integration and sovereignty in the European continent connecting it with its historical foundations; c) interpret the way the concept of sovereignty has been conceived through Latin American state-building processes, taking as a starting point the Colonial Period and pointing out factors of structural weakness in terms of institutionalization ; d) interpret another relevant factor in the construction of Latin American processes of regionalization: the different ideas of regions or "isms": Pan-Americanism and Latin Americanism; e) interpret the concept of sovereignty in the thinking on integration and its three big waves: developmentalism (old regionalism), neo-liberalism (new regionalism), and post-hegemonic regionalism; f) compare the kind of sovereignty in Latin America and Europe and the different impacts it has had on integration processes together and; g) analyze current regionalist perspectives.

\section{The classic and contemporary idea of sovereignty}

Classical sovereignty's fundamental object is the territory and the population within a country and, furthermore, it constitutes a form of power, of which the state is the exclusive subject. For authors such as Bodino (1973) and Hobbes (2003), these two conditions of sovereignty, its object and its subject, must be articulated by a series of laws that refer to the sovereign's authority as being a legitimate and unquestionable leader in all cases, even if there may be gaps or spaces of time when the sovereign, whether a prince or a similar figure, will delegate functions to a subject. Thus, classical sovereignty needs a subject with the necessary power and legal justification or force to implement its authority without contestation. 
Beyond classical sovereignty as an attribute, it is necessary to take into account that sovereignty does not limit one's actions to the domestic dimension of the state, but also operates in an external dimension (Held, 2002, p. 13). In this case, based on the classic fundamental principles, sovereignty denotes autonomy and independency of states against any kind of authority external to it. In the words of Held, "external sovereignty is a quality that political societies possess in relationship to one another; it is associated with the aspiration of a community to determine its own direction and politics without undue interference from other powers" (Hinsley, 1986 quoted in Held, 2002, p. 14).

The concept of sovereignty as an absolute condition of the state is key to being able to interpret XVII century Europe. In that moment, an international scenario emerged, in which relations were between 'sovereign states' with absolute authority, beyond the type of government that ruled each of them. This 'international society' developed its normative assumption from the 1648 Peace of Westphalia, based on the main object of sovereignty: territory.

This form of classical sovereignty occurred in Europe in the context of a few national and geographical segmentations, which are more or less defined, and the formation of governments oriented towards empowering the productive capacity and not merely the extractive capacity of its population, mainly through the contributions of mercantilists and physiocrats (Foucault, 2007, pp. 132-134). In contrast, in the case of the European colonies in Latin America, the generation of wealth was fundamentally of extractive character and focused on obtaining 'precious materials.' This implies, at least, some difficulty for the analysis of sovereignty and stateness ${ }^{1}$ in the subcontinent, since its territories in colonial times operated as overseas extensions of European empires.

On the other hand, the dynamic character of international relations presupposes state sovereignty as its main characteristic. According to Malberg (1948, p. 82), it is defined as "Independence on the outer side and superiority on the inside". Therefore, sovereignty refers to the "right of the state to rule over a defined territory" Held and

\footnotetext{
${ }^{1}$ It is important to define the difference between statehood and stateness. Statehood is an old notion and its definition can be found in all dictionaries and encyclopedias. Statehood is - "the condition or status of being a political state" or "the status of being a recognized independent nation". Stateness focuses on state activity, structures and functions and also defines historical, intellectual and cultural dimensions of this phenomenon. It means the degree to which the instruments of government are differentiated from other organizations, centralized, autonomous, and formally coordinated with each other. Moreover stateness is defined in four dimensions: "(a) creation of the organization for the mobilization of resources: bureaucracy and tax burden; (b) external consolidation of the territory: army; (c) maintenance of internal order: police and judiciary; and (d) state activism in regulatory activities and in economic and social interventionism" (Zaytsev, 2013).
} 
autonomy is the "real power that a nation state has to articulate and pursue their political goals independently" (1997, p. 130).

Nowadays, however, states are required to rely on a stronger form of multilateralism in order to solve global problems; given that problems cross boundaries, the most bona fide approach to solve them is through international cooperation. The latter makes it necessary to transfer regulatory powers to supranational institutions, or to establish networks of international, which impose specific duties on the respective realms of states. Hence, international cooperation does not end sovereignty but amplifies and re-substantiates it (Beck, 2004). Consequently, the concept of absolute sovereignty is today considered anachronistic because of the great amount of international interactions and interdependence, such that it was defined as a faculty divided in multiple agencies - national and international - and limited by the nature of this plurality (Held, 1997).

\section{The concept of sovereignty in European integration thinking}

Integration studies, analyzing the concept both in its conceptual and historical dimensions, usually uses as a parameter and benchmark the process that culminated with the creation of the European Union. This is why authors like Haas (1967) have evaluated Latin American integration as weak, while European integration is considered strong. As a result of the contemporary political reality of an integrated Europe and the fact that most conceptual developments about integration come from that continent, the comparison between the two is sometimes inevitable. However, this comparison is valid if one accepts the linear character of integration, assuming Latin America is the weak end of integration and Europe as the strong end of the same process, or, in other words, that Latin America is going through - not very effectively- a process that will eventually place it on the same path of integration as the European model. However, more than just comparing two points in an integration continuum, one should highlight that there are two historically produced experiences, which result in two different ways of conceiving both integration and sovereignty. Considering this, the history of Europe's integration process will be analyzed in this section and Latin America's case in the following.

It is difficult to understand the conceptualization of integration and sovereignty in Europe as separated from its historical process. Other than the classic references, which appear in the works of Kant (2002) for example, thinking on integration gives shape to the analytical axis of federalism-neofederalism on the one hand, and functionalismneofunctionalism on the other, and has developed in response to the experiences of the World Wars in the first half of the twentieth century. The contemporary developments of federalism come from authors such as Rossi and Spinelli (1941), who based their works 
on politics more than academia, and who argued in the Ventotene Manifesto ${ }^{2}$ that the survival of nation-states' full sovereignty is a danger to the survival of Europe, since the desire to guarantee one's defense resulted in wars. So they propose supranationalism as an alternative solution. This was the idea present in the planning of the European order as, for example, at the 1948 Congress of Europe in The Hague where an economic and political union was discussed in order to prevent European conflicts.

Federalism's classic authors, such as Guy Héraud (1968) and Carl Friedrich (1968), considered this historical preoccupation of an inter-European war and argued that the continent could have moved towards a federation, which would overcome the traditional mistrust of national sovereignty in favor of a supranational European authority. Despite the efforts of both Robert Schuman and Jean Monnet to introduce and develop the notion of supranationality in 1952 with the European Coal and Steel Community (ECSC), in practice, intergovernmentalism has been predominant. However, with the Single European Act (1986) and The Treaty on European Union (1992), the supranationality issue rose again. The result was that neofederalist authors such as Sidjanski (1992), José Martín, and Pérez de Nanclares (1997) have argued that the process was a result of the call for federalization in Europe.

The preoccupation that propels the development of the functionalist view on integration is no different. David Mitrany (1933), one of the founders of this approach, also had in mind the devastations caused by World War I. He argued that nation-states were not effective in facing the challenges posed by the post-war scenario. However, once again, his preoccupation was that this lack of effectiveness could result in a war. He believed that the state was not efficient enough in certain technical functions and that such deficiencies could be more efficiently dealt with at an international level. He maintained that the solution was not an international state, as some federalists suggested, but building international entities that could take over some functions of the nation-state (Mitrany, 1943). His main point was that these institutions would increase interdependence and therefore reduce the risk of war. This focus developed in the 1950 s and is linked to the first steps of economic integration of the ECSC.

In a new stage of functionalist theorization, presented by authors such as Ernst Haas (1958), integration was analyzed in terms of a transfer of loyalty from national institutions to international ones, which would have jurisdiction over national affairs. In the author's opinion, when loyalties do not shift to international authorities but instead remain national, integration is not achieved, but political understanding might be.

\footnotetext{
2 The "Ventotene Manifesto for a Free and United Europe" written by two antifascist militants, is considered today by the European Union as one of its foundational references. See: European Commission, The EU founding fathers.
} 
Again, amid political, academic, and social debates about the desirable future for a devastated Europe, federalist and functionalist perspectives, despite their different prescriptions, were betting on a common interpretation. That is, the struggle to defend the sovereignty of the nation-state was directly responsible for leading Europe, with its epicenter in the Franco-German rivalry, into a general war (Hettne \& Söderbaum, 2008, p. 63).

This basic idea directly challenged ideas associated with political realism that were considered a virtue and the engine of the development of the European system. These ideas include military-industrial competition and mutual deterrence between states, strengthened by alliances, temporary counter-alliances, and geopolitical factors such as rugged terrain. These ideas had secured, since the collapse of the Habsburg Empire, a balance between powers that facilitated both the expansion of free markets and innovative ideas, and political pluralism (Kennedy, 1997). This would work as an "invisible hand" that resulted in indirect benefit to everyone. However, it is also recognized that the complexity and diplomatic secrecy of the balance of power induced alliances which eventually degenerated into a zero sum game. This is a scenario in which the key protagonists sought "total victory", so that sovereignty, power, militarization, and mass ideologies operated together to result in the "era of massacres" of the first half of the twentieth century (Hobsbawm, 1998).

Europe, in seeking the way out of the legacies of rivalry between powers and realpolitik, also pushed for economic reconstruction, which initially depended on U.S. funding, through the Marshall Plan. At the same time this reconstruction was challenged by the rapid advance of Soviet communism in the East (Voyenne, 1965). In order to face these challenges, proposals like Héraud's (1968) argued that the epicenter of political organization of the nation-state should go from the nation to the region, which also involved overcoming the ethnic criteria that shaped the modern state and recognized that cultural similarities and common purposes can be constituents of political units, in this case, Europe.

So, the first or 'old' regionalism has, since the 1950s, put federalism and functionalism in debate. The former suggested that European states should be united by a constitution and federal institutions, have legislative coordination between nation-states, and build a collective identity based on a universality of liberal-democratic values. Functionalism, on the other hand, proposed the creation of organizations with narrowly defined skills which should operate only in critical areas such as trade, transport, productivity, and social policy, and the establishment of institutional arrangements with supranational technocratic economic, rather than political, criteria (Voyenne, 1965; Hettne \& Söderbaum, 2008).

However, referencing the sovereignty types distinguished by Krasner (2000), what was at stake in the functionalist view was not so much Westphalian sovereignty. What mattered was replacing inefficient internal sovereignty, defined in terms of national institutional efficiency, for new forms of public institutions. Nevertheless, 
this did not necessarily require the transfer of political legitimacy and citizen loyalty to these institutions. For Hettne and Söderbaum (2008), this forced depoliticization led to the emergence of the previously mentioned neo-functionalist perspective (Haas, 1967). This approach incorporated the role of politics, highlighting the importance of pro-integration leaders and the concept of "spillover"; politically guided, positive interdependence in the economic field should lead to forms of political integration also.

As previously mentioned, both federalism and functionalism and their neo- counterparts, were developed within the European context and did not propose a universal analysis of integration; thus, it is not surprising that in other parts of the world, such as Latin America, proposals following these lines of thinking were not developed. As it will be explained in the following section, in Latin America the historical experience of integration did not derive from debates on the dangers of sovereignty, rather it was an answer to the challenge posed by weak stateness and extra-regional threats.

\section{Sovereignty, stateness and populism in the process of state building in Latin America}

In this first extract some of the fundamental characteristics in the process of forming Latin American nation-states are explored. It is argued that the historic difficulties that some nation-states have experienced in consolidating their stateness are one of the key elements in understanding their reluctance to relinquish sovereignty to a supranational entity.

Firstly, it is important to consider that the colonial condition of Latin American territory denied it the possibility of relying on a strong institutional presence of European monarchies, comparable to the situation in Europe. Generally, the territories were ruled from a distance and without the opportunity for the central authorities to exercise absolute sovereignty and sufficient coercion to guarantee the strict application of real mandates. From this situation, one part of the analysis can be drawn: the stateness that made progress in Europe had a different pace and teleological evolution to that which developed in the colonies. This can shed some light on the issue of why, in modern times, Europe is undertaking a process of supranational integration while in Latin America the construction of the nation-state that 'began with Independence, has still not finished' (König, 2005, p. 12).

In order to understand the particular dynamics that have shaped Latin American nation-states, some of the key characteristics of their emergence and consolidation processes will be looked at. The Criollo $^{3}$ people did not construct a nation-state founded on religious, ethnic, or cultural criteria but on an ideal of creating a state as a political

\footnotetext{
${ }^{3}$ 2. The Criollo (or Creole people) was a social class in the caste system of the overseas colonies established by Spain in the 16th century. (Note added by translator).
} 
entity. For this reason, inhabitants of Latin American territory sought the promise of legal equality and political freedom through the state. As part of the independence discourse, the Criollos appealed to indigenous history. However, this did not occur as part of a project to construct a state and citizenship that would include indigenous groups, but was used as a political tool to justify their claims before the Spanish. This situation explains the subsequent political and social exclusion of the indigenous from the processes of building citizenship (König, 2005).

Another characteristic is that only since the $19^{\text {th }}$ century has the foundation of national identities started to have national limits, based on the ideas and interests of the elites from various areas. This happened as a result of two factors. Firstly, the awareness of the elite's own resources, which occurred following their participation in the botanical expeditions, and secondly, as a result of the regionalism promoted through their own newspapers. The aforementioned development would be key to the creation of one of the fundamental elements of the state: the ability to govern over a delimited territory. However, embedded in the fight to obtain it was the nationalist project that intended to build a state which would give the inhabitants the possibility to have equality, freedom, and prosperity. This was in stark contrast to the centralist and exploitative policy that would try to boost the Bourbon reforms and that would, along with the Enlightenment ideas of emancipation, be one of the key triggers in the processes of independence (König, 1998).

Furthermore, in order to consolidate the state project, the need to form cultural integration, characteristic of a nation-state, would subsequently have to be considered by the pro-independence elites. Cultural integration, in turn, would bring about a symbolic construction of a nation in order to yield the acceptance and loyalty of its members. At the same time, it would generate the feeling of belonging as to go beyond the fragile territorial state as a mere coercive apparatus (König, 2005).

However, the national projects devised by the Criollos were very vague and did not include the features that a new social and economic organization should have. They merely mentioned the idea of gaining independence from colonial rule, given that they did not plan on giving up their privileges following the independence process. Added to the indeterminacy of the Criollo national project was the fact that the new states did not have the consensus between the different townspeople. Furthermore, politically they still had contradictory local and regional interests, divergent national projects and historic rivalry as well as important differences in the people, which were partly derived from the complex topography. As a response to these difficulties, and in order to build Latin American nations, the political elite resolved to impose their national projects and invent a national collective imaginary. Through said collective imaginary they sought to connect the heterogeneity of the diverse conurbations, based on provincial or local loyalties, through the invention of founding myths and through history and literature. 
Everything that was broadcast, in addition to the civic symbols such as the flag or national anthem, was transmitted through the education system (König, 2005).

The inheritance, in some countries, of the socio-economic structure of the Colonial Pact, which had established predominance of the mono production and exportation sector, contributed to the territorial fragmentation. This meant that institutional procedures were focused on the regions close to the ports and waterways, limiting the effective and total occupation of the territory and therefore creating inequality between the different regions. This disparity was also due to the need to reduce the costs of the monarchy's state apparatus (Kaplan, 1996).

Another complexity that arose in the process of constructing Latin American nationstates was the knowledge of their own territorial resources. This was a result of the aforementioned expeditions and meant that the Criollos identified with specific regions. Following the independence process, this brought about a tendency of the Criollos to favor their own regional development and be suspicious of a central government, believing that this would prevent regional progress (König, 1998).

For this reason, the elite Criollos found themselves facing the dilemma of defining what type of state they should construct. The two options that they considered were centralism and federalism, the latter being preferred not only for its successful execution in the United States but also because it would allow them to maintain regional autonomy. This dilemma generated broader struggles between the elites and regional townspeople, and was another factor that complicated the construction of national identities in the emerging Latin American states (König, 1998).

In the process of building the state, a broad array of conflicts and tensions appeared, some of which resulted in strong levels of violence in many areas of the $19^{\text {th }}$ century new republics. In part, this was due to many social sectors perceiving that the new institutional designs would end up excluding them from the realm of politics. That is to say, it was clear from the start that the Criollo project was not in itself an attempt to establish democratic structures where the people were to be accommodated. The former did not only create tension, but also limited the state's ability to form extended government networks in the new national spaces. This meant that at the time of the republican state's emergence, the material conditions for the full application of the territorial sovereignty of the state and population were not successful.

One example that revealed this weakness in the first decades of the republic was the inability of the state administrations to control, with effective authority, the territories that they had reclaimed following the expulsion of the Spanish. Strong tension could be seen between those that integrated the republican projects and the position of the inhabitants of certain 'liberated' but equally excluded territories. This was particularly evident for Simón Bolívar in 1822, the year in which he arrived in Pasto in an attempt to convince 
the elites of the region to agree to integrate politically, economically, and administratively to the new power structures that he tried to implement as part of his Republican project. However, what was evident was that the acceptance of his new form of national governing was not complete and that even this project was vehemently challenged (Gutiérrez, 2012).

In addition to the latter, one of the fundamental problems for the nation-state was the difficulty that inhabitants felt in showing their loyalty to an abstract entity such as the state. This was due to the fact that in the colonial period they were accustomed to showing their loyalty to a person: a governor, a viceroy or, even more generally, a king. Afterwards, following the power vacuum that occurred as a result of the independence processes, in its place loyalty was entrusted in the Caudillo ${ }^{4}$ who managed the economic and/or military resources (König, 1998; Kaplan, 1996).

The Caudillos emerged from the civil wars as an object and source of authority for the new societies (König, 1998). However, they were also the biggest threat that the new republics faced in maintaining their precarious integration. Only when one of them could impose himself on the others was it possible to consolidate unification of the new states (Oddone, 1986). These so-called unifying autocracies were consolidated in the mid-nineteenth century in most Latin American states, and served as a dam against the separate forces that took place in the wars of independence (Germani, 1962; Fernández \& Nohlen, 1998).

Nevertheless, one of the biggest challenges that the unified autocracies of the urban elites faced, which considered the task of building a state as urgent, was that of trying to integrate rural socio-political forces. These forces would resist being lost to urban interests, reclaim their autonomy and, as a result, would provoke regional disintegration. Moreover, indigenous communities, in regions where they constituted a significant demography, operated as disintegrating forces that had been marginalized in the process of building the state and resisted national integration (Oddone, 1986).

In this context of personalizing power and as part of the process of building a political-state order, which the elite and the major oligarchic groups sought to establish, constitutions and laws that consecrated the State as a presidential, secular, centralized, and democratic regime with a division of power were created. However, in practice the separation of power was only a formality and the presidential regime degenerated into presidentialism, legal or dictatorial, that led to a charismatic and personal embodiment of power in the executive branch. This in turn, limited the legislative and judicial power to make use of the preponderance granted by law enforcement, the military, and the

\footnotetext{
${ }^{4}$ Caudillo normally describes a political and/or military leader or chief especially from Latin America in the 19th century. For example Juan Manuel Rosas in Argentina, José Gervasio Artigas in Uruguay, Agustin Gamarra in Perú, Andrés de Santacruz y Calahumana in Bolivia, Vicente Guerrero in Mexico, José Antonio Páez in Venezuela, José Gaspar Rodríguez de Francia in Paraguay, and Tomás Cipriano de Mosquera in Colombia.
} 
appointment of judges as well as other constitutionally assigned vigorous powers (Kaplan, 1996; Wiarda, 1997; Pastrana \& Vera, 2012; Fernández \& Nohlen, 1998).

In conclusion, there was a lack of real ability on the part of the state institutions to operate effectively in the territory formally under their control. This could have been as a result of three factors. Firstly, the deficits described in the construction of a national identity and in the integration between different regions. Secondly, the personalization of power; and thirdly, the concentration of the state apparatus in a specific urban focus. Facing this situation, the executive branch of power served as society's unified benchmark, resulting in a strong populism ${ }^{5}$ in a large part of Latin American states.

This is relevant because the willingness to transfer sovereignty in integration processes can also be explained as an executive branch behavior. That is to say, as an attempt to increase room for maneuvering against the restrictions imposed by internal factors on the behavior of the executive branch. When domestic institutions have the capability to influence or restrict the executive branch, the latter chooses to cooperate with other heads of state to create binding supranational entities in such a way as to restrict the decision-making influence of these domestic institutions. In contrast, when the executive branch is autonomous from domestic institutions, they tend to favor less the transfer of sovereignty because it does not increase the executive branch's discretion. Instead, intergovernmental approaches prevail, and multiple examples of "personalism" and regional or sub-regional leadership aspirations become commonplace (Koenig-Archibugi, 2004).

\footnotetext{
${ }^{5}$ Populism can be defined as a political strategy with three characteristics. A personal leader to a heterogeneous mass of followers who feel left out and are available for mobilization; the leader reaches the followers in a direct, quasi-personal manner that bypasses established intermediary organizations, especially parties; if the leader builds a new, or revives an old, populist party, it remains a personal vehicle with a low level of institutionalization (Weyland, 2001, p. 381). Moreover, to facilitate comparative analysis of different populist expressions, a synthetic construction of populism can be founded on the following five core properties: 1 . a personal and paternalistic, though not necessarily charismatic, pattern of political leadership; 2 . a heterogeneous, multi-class political coalition concentrated in subaltern sectors of society; 3 . a top-down process of political mobilization that either bypasses institutionalized forms of mediation or subordinates them to more direct linkages between the leader and the masses; 4. an amorphous or eclectic ideology, characterized by a discourse that exalts subaltern sectors or is anti-elitist and/or antiestablishment; 5. an economic project that utilizes widespread redistributive or clientelistic methods to create a material foundation for popular sector support (Roberts, 1995). For instance Álvaro Uribe (Colombian President 2002-2010) approached and conducted foreign policy in the framework of a populist strategy. Foreign policy is one of most effective of the symbolic policies in providing a stage for the actions of a charismatic leader (Pastrana \& Vera, 2011).
} 


\section{The construction of Pan-Americanism and Latin Americanism}

In this section a brief historic reconstruction of the ideas or 'isms' that have played a decisive role in the construction and institutionalization of the current different conceptions of region in the Americas will be explored. This aims to provide an explanatory supplement to the historical factors that have prevented the consolidation of a strong stateness in the nation-states in Latin America.

The narrative surrounding the diverse integration processes in Latin America is usually constructed by examining institutions, taking the middle of the $20^{\text {th }}$ century as a starting point. It then develops in terms of three waves of thought concerning integration. However, it is important to highlight that the ideas that formed regional institutions, which arose in this period, had already been growing since the $19^{\text {th }}$ century. Two contradictory concepts about region emerged: Latin Americanism and Pan-Americanism.

It is relevant to note that Pan-Americanism is a term that was coined in 1889 in the United States. This idea of the region surfaced in the 'panisms' context in the $19^{\text {th }}$ century. The 'panisms' were international ideological movements that sought to group states around a central power, according to common characteristics. Other historic examples were the Pan-Britanism, the Pan-Germanism, and the Pan-Slavism (Ardao, 1986).

The idea of a Pan-America was demarcated by the United States in pursuit of a key interest: to find new markets for its growing industry. This was in line with what it had historically implemented: its policy of expansionism that was to a certain extent territorial and against townspeople south of the United States through methods of conquering, separation, and absorption. However, this policy took on a new form towards the end of the $19^{\text {th }}$ century as an instrument to commercially unite the hemisphere (Ardao, 1986).

In this way, following intense diplomatic efforts on behalf of the White House, the first summit that united the states of the American continent was held in Washington between 1889 and 1890, and was called the International American Conference. Afterwards, during the IV conference in 1910, the office that would be responsible for compiling commercial data between the countries was named the Pan-American Union. At the first meeting, the American states had promised to found this office in Washington. Since then, everything related to movements led by the United States, in the hopes of building the idea of a hemispheric unity, has been called 'Pan-American' (Ardao, 1986).

The concept of Latin America, from which Latin Americanism stemmed, initially came about from the classification proposed by the Frenchman Michel Chevalier in 1836, in the book in which he compiled the editorial chronicles of his trip to the United States. In this text he wrote that he had found Latin and German roots in the New World. He categorized North America as Protestant and Anglophone and in contrast he categorized South America as Latin and Catholic. In this way the Latinity found in South America 
was initially used as an adjective, latin America, that with time would become the noun to name the sub-continent Latin America (Ardao, 1986).

Latin Americanism was born out of the same notion by a group of Hispanic intellectuals living in Paris. It is important to highlight that in this period two events provided the conditions for the emergence and growth of the concept. Firstly, awareness that the most pressing threat to the South American peoples was not the Europeans but the expansionist ambitions of the United States; and, secondly, a growing awareness of "panisms", especially Pan-Germanism and its Zollverein, and Pan-Slavism, for the Latin and Anglophone world (Ardao, 1986).

The Colombian José María Torres Caicedo, one of the aforementioned Hispanic intellectuals, created and expanded the proposal of a united Latin America in 1861, and subsequently in 1865 with the publication of a book regarding the topic. He went on to defend the need for a Latin American Union to oppose the North American doctrine of Manifest Destiny. It would defend, at the same time, the idea that it is necessary to maintain amiable relations with North America, but clarifying that this would only be possible in an environment of equality and reciprocity (Ardao, 1986).

The essence of Latin Americanism was also expressed in celebrated papers such as Our America (1891) by José Martí, who became established as one of the most ardent critics of Spanish colonization and the expansionist Pan-Americanism of the US. Furthermore, it was shown in the Letter from Jamaica (1815) through the clamor with which Simón Bolivar sought the integration of the American peoples as a resistance to the external threat. This was a call for unity, amid the Caudillos' disputes in the context of struggles for independence.

Despite this, the idea of a unified Latin America was still delayed in reaching amalgamation. This was due to the deep-rooted differences in opinion between the Latin American states regarding the precise configuration that the Latin American Union should have, for example, should the US or Brazil be members, and also due to the enormous attraction that the Pan-American Union caused. An example of the differences in opinion came when Bolivar called the Republics, previously Spanish colonies, to the Panama Congress. In response, Santander summoned the United States and subsequently Brazil, demonstrating the split in opinion between the political elites regarding a potentially unified Latin America (Ardao, 1986).

Thus, Latin Americanism and Pan-Americanism were the two regional ideas that emerged in the $19^{\text {th }}$ century and represented the views of regional integration institutions that would emerge in the $20^{\text {th }}$ and $21^{\text {st }}$ centuries. Both ideas had historic milestones in the same year, 1948.

In that year, Pan-Americanism underwent a decisive transformation. It became Inter-Americanism, a change that recognized the existence of different Americas existing 
on the same continent. It also suffered a reaction facing a crisis of legitimacy in PanAmericanism, stemming from the unilateral and expansionist actions of the United States. These situations revealed the need to make the forum Inter-American (Ardao, 1986, p. 166). Said transformation took institutional form in the Inter-American system. The official structure was shaped in the context of the Cold War and would encompass various institutions and treaties: the Inter-American Defense Board, which brought together officials from the continent to collaborate on defense and security issues, the Treaty of Reciprocal Assistance (Rio Treaty), a committee for the defense of Human Rights on the continent (ICHR), a political forum and crisis management organization, the Organization of American States (OAS) and a banking infrastructure that sought to finance developing projects on the continent (IDB).

With regards to Latin Americanism, from within the United Nations a commission that recognizes the appellative Latin America was also established in 1948: the Economic Commission for Latin America of the United Nations (ECLA). The commission had a key influence in shaping the thinking about Latin American integration. Following the formation of ECLAC, the international institutionalization of Latin Americanism continued through the creation of international organizations that represented the idea. Some worth mentioning are: the Latin American Free Trade Association (LAFTA) in 1961, the Special Coordination Committee for Latin America (CECLA) in 1964, and the Latin American Economic System (SELA) founded in 1975 (Ardao, 1968).

\section{The waves of integration in Latin America}

The previous two sections can by synthesized to note two key points. Firstly, that one of the factors that has made Latin American states reluctant to give up their sovereignty is the weak stateness that they have historically held, and secondly, that the divergent conceptions of region that emerged in the $19^{\text {th }}$ century appeared as two different integration projects in the $2 \mathrm{O}^{\text {th }}$ century: a Pan-American (Inter-American) project and a Latin American project. Neither of these projects was able to ensure the transfer of sovereignty, but instead they were able to focus on the defense of sovereignty and the principle of non-intervention as in other aspects of the construction of the region.

The following section will focus on the explanation of the waves of regionalization through which the thinking about integration in Latin America from the mid-twentieth century has been classified. This will be carried out recognizing both the weak stateness of the Latin American nation-states and also the bifurcation between Pan-Americanism and Latin Americanism as points of reference relevant to the interpretation of each wave.

In Latin America, thinking on integration has developed in three waves: the first, based on ECLAC's structural and economic analysis, developmentalism, which began at the end of the forties and had its peak in the 1960s and 1970s. The historical trigger 
for this reflection on integration was not the threat of an international war, but the preoccupation with underdevelopment, which meant that the theme of sovereignty was not thought of in the same terms as in the European experience. Developmentalism served as the analytical framework for integration in Latin America in contrast to the approaches of functionalism and federalism in Europe. Since the end of the 1940s Raúl Prebisch, among others, proposed through the ECLAC to look more closely into Latin American history. The center of his analysis was not how to avoid war, or how to build a stable post war order, but how to improve commercial trade conditions between the Northern and Southern hemispheres, or as he would say, between the center and the periphery.

His starting point was that while the center had a modern production apparatus, specialized and diversified, the peripheral zones had an extractive, unspecialized, mono-exporting character. This perspective is inspired by the analysis of authors such as André Gunder Frank (1965), Arghiri Emmanuel (1964), and Samir Amin (1974), who follow the Marxist tradition. There were also important Latin American authors, such as Prebisch (1986), Furtado (1956), Santos (1996), and Cardoso and Faletto (1977). They all agreed that differences in terms of trade tended to deepen and make the conditions of the periphery worse. Accordingly, the thinking revolved around how to overcome this difficulty and the approach proposed pointed to strengthening the state hand in hand with 'closed regionalism', which essentially implied the application of protectionist and import substitution strategies.

After this first wave of Latin American integrationist thought, a second wave called "open regionalism" arose in the 1990s, consistent with the neoliberal vision that was gaining strength at the time, and in which integration was replaced by the openness and harmonization of markets, as a basis for inclusion in the international arena through increased competitiveness. The idea was to first open markets with neighboring countries rather than great powers. Organizations such as the Common Market of the South (MERCOSUR) ${ }^{6}$ were founded during this era and previously existing ones like the Andean Pact ${ }^{7}$ changed their integration strategy from developmentalism to open regionalism. While the purpose of this wave was not the strengthening of stateness, it also did not lead to the transfer of sovereignty because the goals were primarily commercial, and political integration was not a relevant issue.

The third wave, called post-hegemonic ${ }^{8}$ (Riggirozzi \& Tussie, 2010), developed at the beginning of the $21^{\text {st }}$ century (Serbin, 2011). This wave has been built in regards to

\footnotetext{
${ }^{6}$ Today, however, MERCOSUR is oriented by post-hegemonic regionalism, especially, because it has taken steps toward positive integration, such as emphasizing the social and political aspects of integration.

7 Renamed since 1996 as the Andean Community (AC).

8 Thinking about the latest debates we have decided to adopt the post-hegemonic concept of regionalism instead of the post-liberal one. Especially considering that the projects classified on
} 
concepts such as region and regionalism. This kind of regionalization has been defined as post-hegemonic, as it is not guided exclusively by trade integration, but implies a re-politicization of regional formulation as a resistance to US hegemony, and it is built through collective identity elements, such as opposition to neoliberal individualism, which ask for social welfare improvement. It is a hybrid model concerned with growth and economic stability, but also with social justice and a relatively new way of confronting the United States' hegemony (Riggirozzi \& Tussie, 2010). Overall, the Bolivarian Alliance for the Peoples of our America (ALBA) and the Union of South American Nations (UNASUR) represent this wave and aim to be the answer to the open regionalism approach and the hegemony of the United States. The former is more confrontational, seeking to build a Latin American discourse and focusing especially on the social aspects of cooperation. The latter is more pragmatic, with the development of cooperative approaches on topics such as crisis management, political coordination, physical integration, and regional security.

In the analysis of the relationship between integration and sovereignty in Latin America, the first conclusion is that in neither the first nor the second wave of Latin American integration, the transfer of sovereignty was sought; rather there were even attempts to strengthen sovereignty. Unlike Europe, where the main threat to Westphalian sovereignty came from the European states themselves and the resulting solution was to modify relationships between them, in Latin America the principle of non-intervention has traditionally been respected and external interference has mainly come from players outside the region. Therefore, the relationships to be modified are not those that occur between neighbors, as in the case of Europe, but between Latin American states and extra-regional powers. The result was that what was sought was not a formula to get a group of neighboring states to cease being mutual threats, but how to increase independence from extra-regional powers and make viable the projection of their own autonomy; in other words, to constantly strengthen Westphalian sovereignty reaffirming the Calvo and Drago doctrines as opposed to external interference (Serbin, 2011).

Thus, while in Europe integration is understood as an alternative to the hazards of strong sovereignty, to the point that Haas (1958) held the view that that integration implied the transfer of sovereignty, in Latin America the transfer of sovereignty was not a concern. Therefore, the idea of integration did not lead the processes, structural underdevelopment did. When conceiving that weakness in manufacturing is the cause of the periphery's condition, and that state-centric protectionism is a solution, the purpose of integration was to strengthen Latin American stateness.

this wave do not entirely abandon political nor economic liberalism. They do, however, propose the creation of more autonomous regional projects that exclude the hegemon: the United States. 
Post-hegemonic regionalism shows different paths to consolidate a regionalization process different from those of Europe, guided by functionalism and federalism, as well as from those paths of the first two waves, which tied the regionalization process to the market. Entities such as ALBA and UNASUR innovate ways of understanding social cohesion and regional identity. Though they do not seek to foster an integration process in the sense of transfer of sovereignty, they are trying to promote the necessary political coordination to build effective regional governance.

\section{South America: Sovereignty and regionalization}

While in Europe the idea of "region" was proposed as an alternative to the national criteria that shaped the modern state, in the hope that this would allow Europe to overcome confrontations (Héraud, 1968), in Latin America the approach of a delimited space composed of common elements was built around the idea of an extra-regional threat to sovereignty. In fact, the idea of space that appeared in the ECLAC thinking in the mid-20 ${ }^{\text {th }}$ century, continuing ideas of $19^{\text {th }}$ century Latin Americanism, which spoke of the unity of Latin America as a defensive strategy of multiethnic and multicultural nations against Anglophone and Francophone threats (Ardao, 1986).

That is why, while the conception of the European region included from the beginning postwar concerns about an integration including the transfer of sovereignty, in Latin America the idea of a region did not challenge state-centric logic as the guiding principle of the region. During the 1990s, when the purpose of international integration was more focused on trade than political dimensions, not only was thought of the formation of a region minimal, but in the absence of policy with integration objectives, the issue of sovereignty was not brought into discussion, or it failed to come into practice, as in the case of the AC.

On this point, a reflection about Haas' neo-functionalism is valid (Haas, 1967, pp. 323-325). When comparing European and Latin American integration, he argues that the latter is weak because it is based on economic purposes that are difficult to sustain in the long term. His argument is that integration is not the product of altruism but of convenience, because stakeholders are committed to it only if it is for their own benefit. Therefore, the first thing that usually occurs is economic integration, as this is where the benefits are more tangible in the short term.

The interesting thing is that, in analyzing the Latin American case, he attributes its weakness to the fact that while integration begins on an economic level, in the long term it is ephemeral because from there, integration can only move forward if it is guided by a deeper philosophical or ideological commitment. Otherwise, integration based on economic considerations eventually erodes. While projects such as the ECSC, the European Economic Community and the European Atomic Energy Community (EURATOM) were essentially sustained by economic considerations, they were in step early on with the 
political calculation for the pacification and regionalization of Europe. In contrast, both ECLAC integration, as analyzed by Haas, and the neoliberal integration of the 1990s, were not sustained by long-term political projects.

This only began to change in the late $20^{\text {th }}$ century when a post-hegemonic integration scheme appeared. The end of the Cold War marked the beginning of a period of transition between bipolarity and multipolarity, in which new countries began to emerge as significant global players. Part of these emergent countries' strategy to gain influence has been to project leadership in their respective regions. One of those countries, Brazil, began to reconceptualize the idea of region in Latin America, which led to a new delimitation: South America. Following the Latin Americanist tradition, South America is a space that seeks autonomy and excludes the United States and Canada, but it also takes distance from Latin Americanism by excluding Mexico and Central America. In the first steps of this redefinition of space, integration starts from the economic promotion through MERCOSUR. Then, and in parallel with the construction of UNASUR, the emergence of these political and philosophical purposes, which Haas identified as missing, became visible.

In the same vein, MERCOSUR and UNASUR have begun to shape a new region as part of Brazilian foreign policy strategy. Both organizations, the first with a trade focus and the second more political, are the institutional face of the South American regionalization process. Even though it is possible to recognize UNASUR as the spearhead of the third, post-hegemonic, integration wave, supranationality and shared sovereignty are not part of this organization's objectives. Again, the reason is strongly related to the lack of discussion about national sovereignty, the low level of consolidation of stateness that remains in the member states, and ultimately to Brazil's reluctance to cede sovereignty.

\section{Perspectives on the Latin American regionalization processes: Between old and new 'isms'}

It is important to highlight that the view presented to us of the construction of the region in the American continent is not unique. There are still different views regarding how to conceptualize and define the region. Pan-Americanism maintains the shape of the InterAmerican system (OAS, IDB, ICHR) and it might be strengthened with the United States' 'return' to the region, after more than a decade of relative absence. On the other hand, there are also organizations that maintain Latin Americanist and Bolivarian discourses (CELAC, ALBA). Thirdly, as mentioned in the previous section, it is possible to find two organizations that represent an idea of the South American region (MERCOSUR, UNASUR).

Along with the various options for delimitation, most of the different institutions and organizations that represent these possibilities emphasize one aspect of integration 
or another and correspond to different waves of regionalization. For example, in commercial terms, MERCOSUR and the newly-formed Pacific Alliance (PA) can be found to promote the inclusion of their members in the international economy in different ways. The former currently adopting the post-hegemonic regionalism and the latter being more closely related to open regionalism. Also, there are at least three organizations that seek to promote regional political coordination: UNASUR, CELAC, and ALBA.

However, as the text has highlighted, not one of these organizations, waves of regionalization, nor ideas of region, contemplates the possibility of giving up sovereignty. This can be linked to historical experiences in the construction of many of the Latin American nation-states, and especially to their weak stateness which has brought them to look for the consolidation of sovereignty through regionalization processes instead of its transfer.

Nevertheless, despite the challenges of reconciling multiple integration processes, this does not necessarily warrant the interpretation of Latin American integration as 'weak' or 'fragmented', but rather that it can be understood as a division of labor between different regional organizations where common ground can be found in spite of differences. This allows the institutional architecture of the Latin American case to be categorized as different regional governance complexes, which are segmented, but where cooperation and complementarity prevails (Nolte, 2014).

\section{Conclusions}

Sovereignty cannot be understood as an attribute of government that is based solely on a regulatory framework. Undoubtedly, a key element in the effective deployment of sovereignty is that the state has institutions at both organizational and legal levels in order to be a legitimate government throughout the territory and population. Looking at the Latin American experience of sovereignty building, a low level of stateness has been an important and influential factor. It has limited the strength of sovereignty in several countries of the region and served as a limiting factor in the consolidation of the regional integration spaces that include the transfer of sovereignty.

In Europe, the theoretical and practical developments of integration occurred in response to the two World Wars, which called into question the system of sovereign nation-states, given their propensity to lead to clashes between neighboring countries. In contrast, national sovereignty in Latin America never posed the threat of large-scale international wars, and therefore integration is not thought of as a process to transfer sovereignty or to diminish conflict, but as sociopolitical alliances between similar countries, which through the creation of economic ties could address underdevelopment.

The concept of region emerged in Europe amid the search for a criterion of political organization that could replace the nation-state logic. Meanwhile, in Latin America, "region" was always understood as the way of conceiving the space that allowed it to 
exclude the United States and Europe, who were the main threats to sovereignty. Thus, "region" in Latin America has been a project to strengthen sovereignty.

In Latin America, the unfinished state-building process has had an important impact on the regionalization processes. The reluctance to transfer sovereignty to a supranational institution can be linked to the historical lack of real ability on the part of the state institutions to effectively operate in the territory formally under their control. This is a situation that can be interpreted as a consequence of the colonial experience, the concentration of state institutions in a specific urban focus, the difficulties in the construction of a national identity, and in the integration between different regions. Also due to the emergence of Caudillos that struggled for the dominance and autonomy of their own regions, the subsequent strong presidentialism, and the recurrence of populism.

\section{References}

Amin, S. (1974). Capitalismo periférico y comercio internacional. Buenos Aires: Ediciones Periferia.

Ardao, A. (1986). Panamericanismo y latinoamericanismo. In Zea, L. (Coord.). América Latina en sus ideas (pp. 157-171). Ciudad de México D.F.: Siglo XXI Editores.

Beck, U. (2004). Poder y contrapoder en la era global: La nueva economía política mundial. Barcelona: Paidós.

Bodino, J. (1973). Los seis libros de la República. Madrid: Aguilar,

Cardoso, F. H., \& Faletto, E. (1977). Dependencia y desarrollo en América Latina. Buenos Aires: Siglo XXI Editores.

Emmanuel, A. (1964). El intercambio desigual. La Habana: Revue Economica.

Fernández, M. \& Nohlen, D. (1998). El presidencialismo latinoamericano: evolución y perspectivas. In Nohlen, D. \& Fernández, M. (Eds.). El presidencialismo renovado. Instituciones y cambio político en América Latina. Caracas: Nueva Sociedad.

Foucault, M. (2007). Seguridad, territorio y población. Buenos Aires: Fondo de Cultura Económica.

Friedrich, C. J. (1968). Trends of Federalism in Theory and Practice. London, United Kingdom: Pall Mall Press.

Furtado, C. (1956). Uma economia dependente. Rio de Janeiro: Ministério da Educação e Cultura - Serviço de Documentação.

Germani, G. (1962). Clases populares y democracia representativa en América Latina. Desarrollo Económico, 2(2), 23-43. 
Gunder, A. (1965). Capitalismo y subdesarrollo en América Latina. La Habana: Editorial de Ciencias Sociales.

Gutiérrez, J. (2012). Los indios de Pasto contra la República (1809-1824): las rebeliones antirrepublicanas de los indios de Pasto durante la guerra de independencia. Bogotá: ICAHN.

Haas, E. (1958). The Uniting of Europe. Political, Social and Economical Forces 19501957. London: Stevens and Sons.

Haas, E. (1967). The Uniting of Europe and the Uniting of Latin America. Journal of Common Market Studies, 5(4), 315-343.

Held, D. (1997). La democracia y el orden global, del Estado moderno al gobierno cosmopolita. Madrid: Editorial Paidós.

Held, D. (2002). Derechos de los Estados, derechos de los pueblos: tres modelos de soberanía. Revista Post Data, 8, 11-62. Recuperado de http://www.revistapostdata. com.ar/2011/12/derecho-de-los-estados-derecho-de-los-pueblos-tres-modelosde-soberania-david-held/

Héraud, G. (1968). Les principes du fédéralisme et la fédération européenne. Paris: Presses d'Europe.

Hettne, B., \& Söderbaum, F. (2008). The Future of Regionalism: Old Divides, New Frontiers. In Cooper, A. F., Hughes, C., \& Lombaerde, P. (Eds.). Regionalisation and Global Governance: The Taming of Globalisation? (pp. 61-79). New York: Routledge.

Hobbes, T. (2003). Leviatan. O la materia forma y poder de una república eclesiastica y civil. Buenos Aires: Editorial Losada.

Hobsbawm, E. (1998). Historia del siglo XX. Buenos Aires: Editorial Crítica.

Kant, I. (2002). Sobre la paz perpetua. Madrid: Editorial Tecnos.

Kaplan, M. (1996). El Estado Latinoamericano. México, D.F., México: Universidad Nacional Autónoma de México.

Koenig-Archibugi, M. (2004). International Governance as New Raison d'État? The Case of the EU Common Foreign and Security Policy. European Journal of International Relations, 10, 147-188.

Kennedy, P. (1997). Auge y caída de las grandes potencias. Barcelona, España: Plaza \& Janés.

Kissinger, H. (1995). La diplomacia. Ciudad de México D.F.: Fondo de Cultura Económica. 
König, H.-J. (1998). Los movimientos de independencia hispanoamericanos. In Janik, D. (Coord.). La literatura en la formación de los Estados hispanoamericanos (pp. 9-33 ). Frankfurt: Vervuert.

König, H.-J. (2005). Discurso de identidad, Estado-nación y ciudadanía en América Latina: Viejos problemas-nuevos enfoques y dimensiones. Historia y Sociedad, 11, 9-32.

Krasner, S. (2000). La soberanía perdurable. Colombia Internacional, 53, 25-42.

Malberg, R. C. de. (1948). Teoría general del Estado. Ciudad de México D.F.: Fondo de Cultura Económica.

Martín, \& Pérez de Nanclares, J. (1997). El sistema de competencias de la Comunidad Europea. Germen iusinternacionalista versus vocación federal. Madrid: McGraw-Hill.

Mitrany, D. (1933). The progress of International Government. New Haven: Yale University Press.

Mitrany, D. (1943). A Working Peace System. An Argument for the Functional Development of International Organisation. Chicago: Quadrangle Books.

Mitrany, D. (1965). The Prospect of Integration: Federal or Functional? Journal of Common Market Studies, 4(1), 119-149.

Nolte, D. (2014). Latin America's New Regional Architecture: A Cooperative or Segmented Regional Governance Complex? Florence: EUI working papers.

Oddone, J. (1986). Regionalismo y nacionalismo. En L. Zea (Coord.). Regionalismo y nacionalismo (pp. 201-238). Ciudad de México D.F.: Siglo XXI Editores.

Pastrana, E., \& Vera, D. (2011). La estrategia populista en la política exterior de Álvaro Uribe. Revista Papel Político, 16(2), 599-635.

Pastrana, E., \& Vera, D. (2012). La estrategia populista en la política exterior: las relaciones colombo-venezolanas en la era Uribe-Chávez. In Márquez, M., Pastrana, E., \& Hoyos, G. (Eds.). El eterno retorno del populismo en América Latina y el Caribe (pp. 307-350). Bogotá: Clacso.

Prebisch, R. (1986). El desarrollo económico de la América Latina y algunos de sus principales problemas. Desarrollo Economico, 26, 479-502.

Riggirozzi, P., \& Tussie, D. (2010). The Rise of Post-Hegemonic Regionalism in Latin America. In Riggirozzi, P., \& Tussie, D. (Eds.). The Rise of Post-Hegemonic Regionalism. The Case of Latin America (pp. 1-16). New York: Springer.

Roberts, K. (1995). Neoliberalism and the Transformation of Populism in Latin America: The Peruvian Case. World Politics, 48(1), 82-116. 
Rossi, E., \& Spinelli, A. (1941). The Ventotene Manifesto. Ventotene: The Altiero Spinelli Institute for Federalist Studies.

Santos, T. (1996). Crisis económica y crisis política. Santiago de Chile: Mimeo CESO.

Sidjanski, D. (1992). El futuro federalista de Europa. De los orígenes de la Comunidad Europea a la Unión Europea. Barcelona: Ariel.

Serbin, A. (2011). Regionalismo y soberanía nacional en América Latina: los nuevos desafíos. In F. Aravena (Ed.), América Latina y el Caribe. Multilateralismo vs. soberanía: la construcción de la Comunidad de Estados Latinoamericanos y Caribeños (pp. 49-98). Buenos Aires: FLACSO.

Voyenne, B. (1965). Historia de la idea europea. Barcelona: Labor.

Weyland, K. (2001). Clarifying a Contested Concept: Populism in the Study of Latin American Politics. Comparative Politics, 34(1), 1-22.

Wiarda, H. (1997). Determinantes históricas del Estado latinoamericano: la tradición burocrática-patrimonialista, el corporativismo, el centralismo y el autoritarismo. En M. Vellinga (Coord.), El cambio del papel del Estado en América Latina (pp. 45-73). México D.F.: Siglo Veintiuno Editores.

Zaytsev, D. (2013). Indices of "Stateness" and Governance: Damaging Fallacies and Possibly Optimizing Choices. Paper presented at the International Conference on Public Policy, Grenoble, Jun. 2013. 